Iranian Journal of Breast

Diseases. 2022; 14(4):45-61.
Original Article

\section{Inhibitory Effect of miRNA-145 on PD-L1 Expression in Breast Cancer Cell Line}

\author{
Hajibabaei $S^{1}$, Sotoodehnejadnematalahi $F^{1}$, Nafisi $N^{2}$, Zeinali $S^{3}$, Azizi \\ $\mathbf{M}^{3^{*}}$ \\ ${ }^{1}$ Department of Biology, School of Basic Science, Science and Research \\ Branch, Islamic Azad University, Tehran, Iran \\ ${ }^{2}$ Breast Surgery Department, Iran University of Medical Sciences, Tehran, Iran \\ ${ }^{3}$ Molecular Medicine Department, Biotechnology Research Center, Pasteur \\ Institute of Iran, Tehran, Iran
}

Receive: 7/9/2021

Accepted: 30/11/2021

"Corresponding Author: mazizi528@gmail.com

Ethics Approval: Not Applicable

\begin{abstract}
Introduction: PD-L1 is one of the most important immune control molecules in breast cancer and plays an important role in suppressing the immune system against tumor cells. Controlling the expression of PD-L1 at mRNA level using miRNA inhibitors could be helpful strategy for cancer treatment. In this study, considering the possible role of miR-145 as a tumor suppression in breast cancer, its involvement in reducing PD-L1 expression in breast cancer cell lines has been investigated.

Methods: First, the targeting of miRNA-145 on 3 'UTR of PD-L1 gene was confirmed using bioinformatics software and then by luciferase dual reporter assay. The expression level of miRNA-145 was measured in breast cancer cell lines compared to normal line. After transfection of miRNA-145 into breast cancer cell lines, qRTPCR was used to evaluate the effect of miRNA-145 on PD-L1 expression.
\end{abstract}

Results: we showed that decreased expression of miRNA-145 in breast cancer cell lines was directly related to increased PD-L1 expression $(\mathrm{r}=-0.6175, \mathrm{P}$ value $=0.0457)$. In addition, increased expression of miRNA-145 in breast cancer cell lines MDA-MB231, BT549 and MCF7 significantly reduced PD-L1 expression $(1.938 \pm 0.212,1.784 \pm 0.03$ and $0.083 \pm 0.02$ respectively).

Conclusion: Our findings suggest that miRNA-145, by targeting the PD1/PD-L1 pathway and reducing PD-L1 expression, may be a therapeutic agent to prevent the progression of breast cancer.

Keywords: PD-L1, miRNA-145, Breast Cancer 


\section{Introduction}

Breast cancer is the uncontrolled growth of abnormal cells that occur in different breast tissues. In recent years, the treatment of BC has made significant progress, leading to the development of targeted therapy [1]. One of the most likely candidates for tumor immune-microenvironment in the incidence of $\mathrm{BC}$ is the change of PD-L1 expression. Appearance evidence reports that the miRNA network entirely controls the PD-L1 and PD-1 levels, consequently having a profound regulatory effect on the expression of immune checkpoint-related genes through a complex regulatory mechanism [2]. The main purpose of this study was to reduce the expression of PD-L1 by increasing the expression of miRNA-145 as a tumor suppressor in three breast cancer cell lines.

\section{Materials \& Methods}

The expression level of PD-L1 and miR-145 were examined in $\mathrm{BC}$ cell lines by real time PCR and the targeting effect of miR-145 on PD-L1 was evaluated by luciferase reporter system. In vitro overexpression of miR-145 was used to figure out whether this miR could decrease the PD-L1 expression in mRNA levels in BC cell lines.

\section{Results}

miRNA-145 significantly reduces luciferase activity compared to disrupted oligonucleotides (scrambled). Overexpression of miRNA-145 to MDAMB231, BT549 and MCF7 reduced luciferase activity by $43.5 \% 610.61,45.4 \%$ 0.0 .42 and $46.5 \% 410.41 \%$, respectively (figure 2B, $\mathrm{P}<0.01$ ).

The expression of miR-145 was significantly downregulated in $\mathrm{BC}$ cell lines compared to their control, and its downregulation was negatively correlated with PD- L1 overexpression $(\mathrm{r}=-0.6175, \mathrm{p}$ value $=$ 0.0457) (figure 3A, B, C). Increased expression of miRNA-145 decreased PD-L1 level in MDA-MB231 to $59 \pm 0.537$, BT549 to 25.90 .50 .541 and in MCF7 to $0.547 \pm$ $9.3 \%$, compared with untransfected cells (figure 3D).

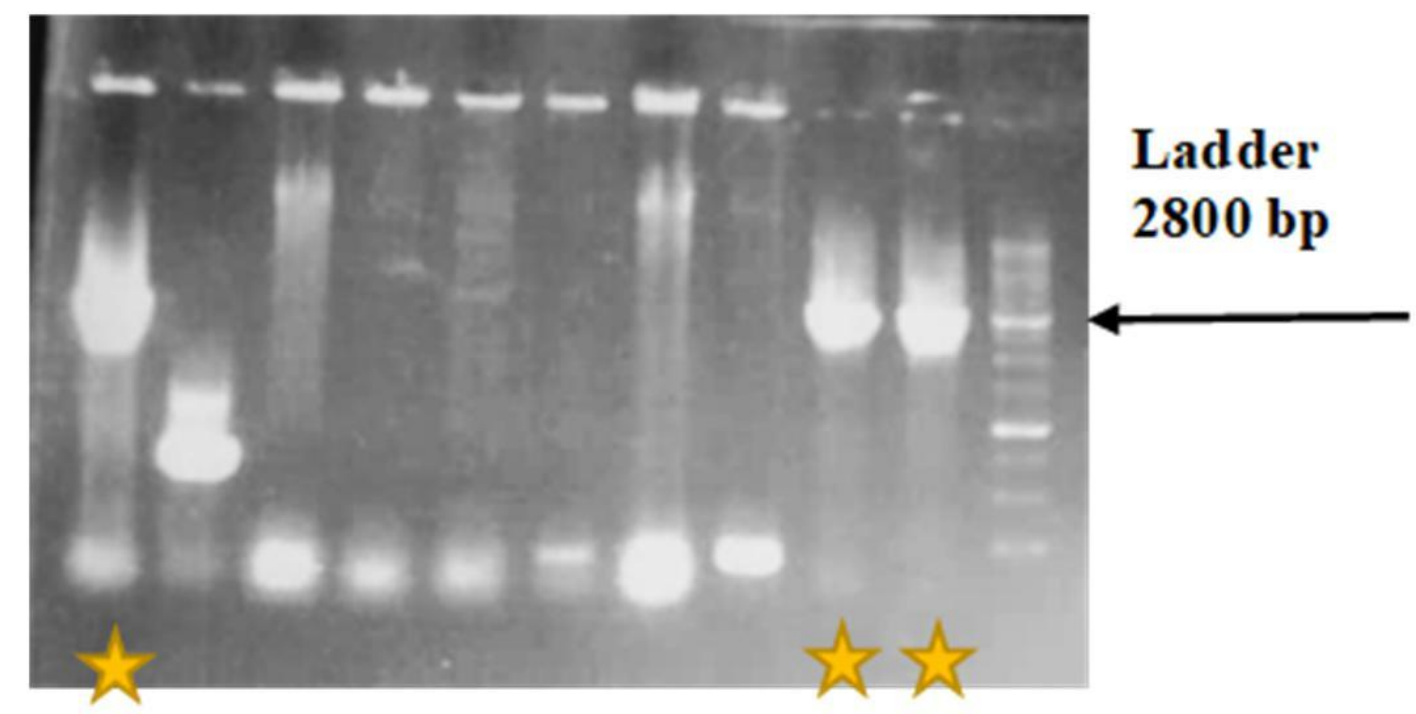

Figure 1: Detection of PD-L1 3'UTR PCR Cloning Product. Row 1 from Right: Ladder, Rows 2, 3, and 10: Positive Colonies Containing 3'UTR (2800bp) Fragment of the PD-L1 Gene Inside the PsiCHECK-2 Vector Grown in Top 10 F 'Bacteria 
A

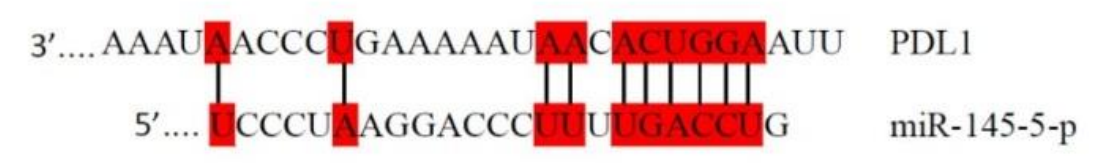

B

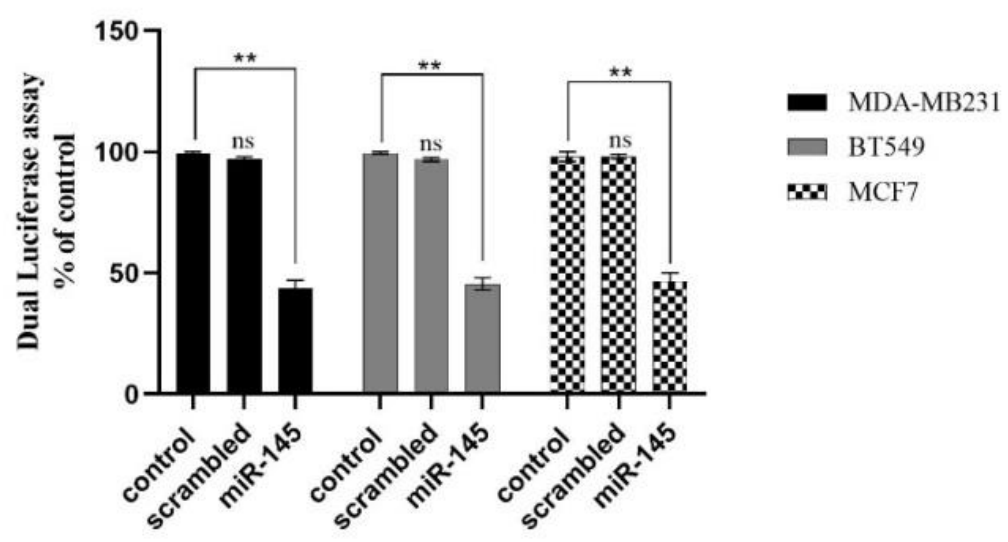

Figure 2: Targeting of PD-L1 by miRNA-145 in Breast Cancer Cells

A

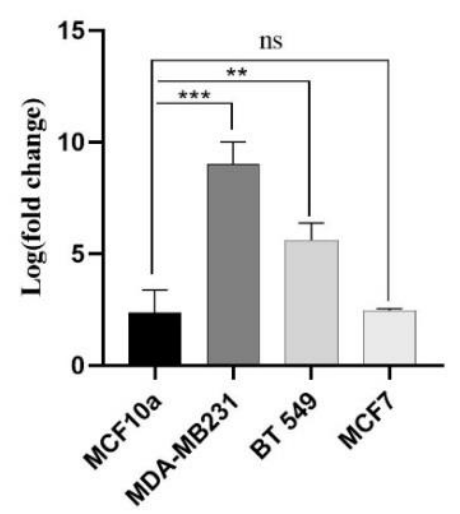

C

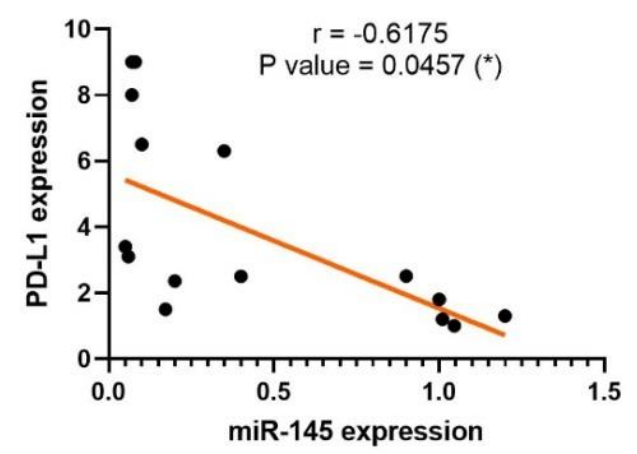

B

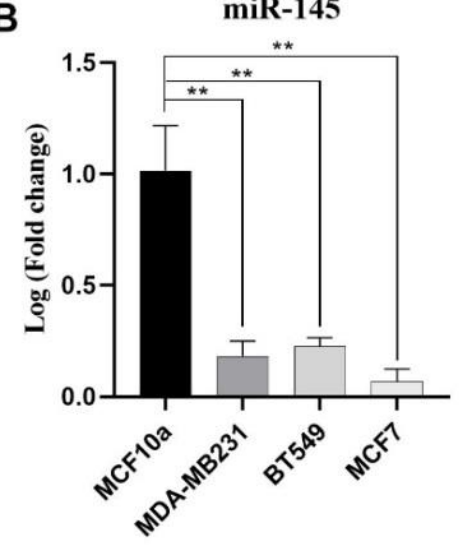

D

PD-L1

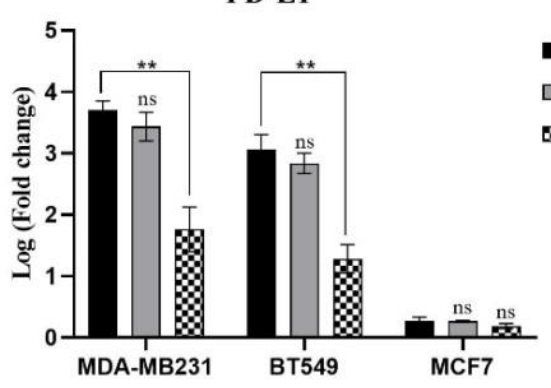

Figure 3: Expression of PD-L1 and miRNA-145 in Breast Cancer Cell Lines 
Figure 1: Detection of 3UTR PCR Product of PD-L1 Gene on Gel

\begin{tabular}{clr}
\hline Gene & \multicolumn{1}{c}{ Sequence of oligonucelotides from 5' to 3' for PCR analysis } & Product \\
\hline PD-L1 & $\begin{array}{l}\text { Forward: CCGCTCGAGCAGATACACATTTGGAGGAGA } \\
\text { Reverse: ATAAGAATGCGGCCGCTGTGCAGGATTCAAAAGCAT }\end{array}$ & 2800 bp \\
\hline Gene & \multicolumn{1}{c}{ Sequence of oligonucelotides from 5' to 3' for real time-PCR analysis } & Product \\
PD-L1 & Forward: GTGATCCGCTGCATGATCAG & $151 \mathrm{bp}$ \\
& Reverse: GGTAGCCCTCAGCCTGACATG & $152 \mathrm{bp}$ \\
GAPDH & Forward: GAAAGCCTGCCGGTGACTAA & $180 \mathrm{bp}$ \\
& Reverse: GCGCCCAATACGACCAAATC \\
miR-145-5p & Forward: GTCCAGTTTTCCCAGGAATCCC & \\
Stem loop & Reverse: AGACTGCACCTGTCCGG & $64 \mathrm{bp}$ \\
miR-145-5P & CAATAGACTACACCTGTCCGGTCCCTGCGTCCTGTAGTCTAATTGAGGGAT & \\
\hline
\end{tabular}

\section{Discussion}

Breast carcinogenesis is a process involving the dysregulation of tumor suppressor genes and oncogenes [3]. The PD- 1/PD- L1 pathway is important as an immunosuppressant, and it is deregulated in a wide range of human cancers [4], including BC. PD-L1 is involved in tumorigenesis with anti-tumor immunosuppression; obstruction makes it a valuable therapeutic target for a variety of human cancers. Identifying the molecular mechanisms involved in regulating the PD- 1/PD- L1 pathway through breast tumorigenesis could help improve new strategies aimed at the antitumoral immune response against $\mathrm{BC}$. miRs are also important regulators of gene expression and have been deregulated with an increasing number of cancer [5]. It is important to achieve efficient methods to increase the expression of tumor suppressor miRNAs for the treatment and control of cancer or its complications. One of the tumor suppressor miRNAs that has been reduced in many cancers, including ovarian, breast, lung, and colon cancers, is miRNA-145 [6]. In the present study, using bioinformatics analysis, we identified region 3'UTR of the PD- L1 gene as a potential target for
miRNA-145, suggesting its possible role in escaping tumor cells from the immune system. Subsequently, we showed that misregulation of miRNA-145 in breast cancer cells was directly related to increased PD-L1 expression, suggesting that miRNA145 may play a role in post-transcriptional regulation of PD-L1 expression.

In this study, dual luciferase assay confirmed that miRNA-145 could target specific regions of PD-L1 '3'UTR and significantly reduce its expression $(P<0.01)$. Also, the results of qRT-PCR and a significant decrease in PD-L1 expression after miRNA145 transfection in the breast cancer metastatic cell line (MDA-MB231, BT549) by $1.938 \pm 0.212$ and $1.784 \pm 0.03$, respectively Compared with the nonmetastatic cell line (MCF7, $0.083 \pm 0.02$ ) of breast cancer, indicates that a significant decrease in miR-145 is involved in an increase in PD-L1 and ultimately breast cancer metastasis. According to this study, increasing miRNA-145 expression in breast cancer cells significantly reduced PD-L1 expression at the mRNA level, reducing the function of miRNA-145 in PD-L1 gene expression in $\mathrm{BC}$. 


\section{Conclusion}

Our findings suggest that miRNA-145, by targeting the PD1/PD-L1 pathway and reducing PD-L1 expression, may be a therapeutic agent to prevent the progression of breast cancer.

\section{References}

1. Lucy M, Czerniecki BJ. Immunotherapy for breast cancer is finally at the doorstep: immunotherapy in breast cancer. Annals of surgical oncology. 2018; 25(10):2852-7.

2. Wang Q, Lin W, Tang X, Li S, Guo L, Lin Y, et al. The roles of microRNAs in regulating the expression of PD-1/PD-L1 immune checkpoint. 2017; 18(12):2540.

3. Osborne C, Wilson P, Tripathy DJTo. Oncogenes and tumor suppressor genes in breast cancer: potential diagnostic and therapeutic applications. 2004; 9(4):361-77.

4. Xu YJ, Zhao JM, Ni XF, Wang W, Hu WW, Wu CP. LncRNA HCG18 suppresses CD8+ T

cells to confer resistance to cetuximab in colorectal cancer via miR-20b-5p/PD-L1 axis. Epigenomics. 2021; 13(16):1283-99.

5. Lin RJ, Lin YC, Chen J, Kuo HH, Chen YY, Diccianni MB, London WB, Chang $\mathrm{CH}$, Alice LY. MicroRNA signature and expression of Dicer and Drosha can predict prognosis and delineate risk groups in neuroblastoma. Cancer research. 2010;70(20):7841-50.

6. Cui SY, Wang R, Chen LBJJoc, medicine $m$. Micro RNA-145: a potent tumour suppressor that regulates multiple cellular pathways. 2014; 18(10):1913-26. 
مقاله يُروهشى

\section{بررسى اثر مهارى miRNA-145 بـر ميـزان بيـان PD-L1 درو \\ سلولهاى سر طانى يستان}

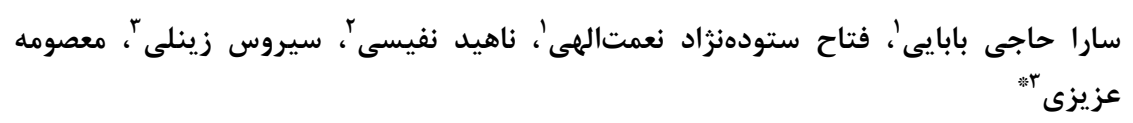

' كروه زيست شناسى، دانشكده علوم و فناورىهاى همكرا، واحد علوم و تحقيقات، دانشگاه آزاد اسلامى،

تهران، ايران

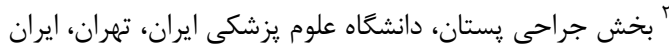

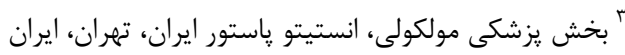

فصلنامه بيمارى هاى يستان ايران

$|\varepsilon \cdots !| \varepsilon(\varepsilon): \varepsilon 0-7 \mid$
جكيده

مقدمه:Programmed cell death ligand 1) PD-L1) بهعنوان يكى از مههمترين مولكولهاى كنترل كننده سيستم ايمنى در سرطان يستان به شمار مىآيد و نقش مهمى در سركوب سيستم

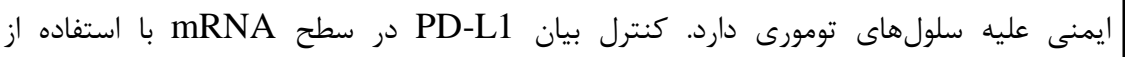
miRNA

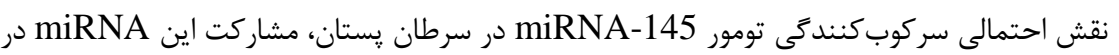

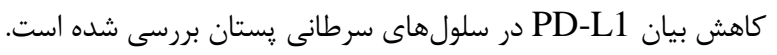

روش بررسى: ابتدا هدف گيرى miRNA-145 بر روى 3’UTR زن PD-L1 با استفاده از

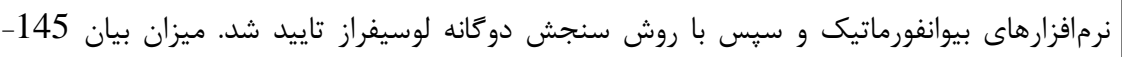

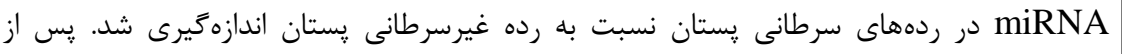

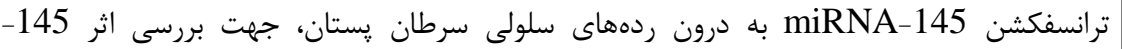
miRNA بر ميزان بيان PD-L1، روش

يافتهها: در مطالعه حاضر، با استفاده از نرمافزارهاى بيوانفورماتيك و سنجش لوسيفراز دو PD-L1 به عنوان يك هدف براى 3’UTR

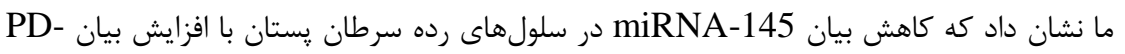

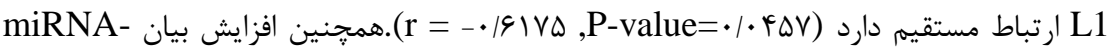

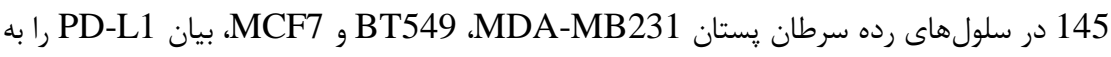

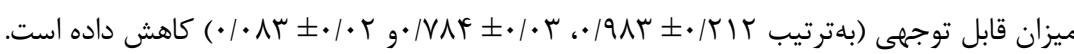
نتيجه كيرى: يافتهاى ما نشان مى دهد كه miRNA-145 با هدف

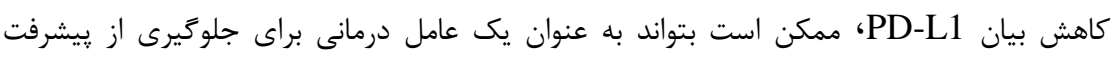
سرطان يستان باشد. | وازههاى كليدى: PD-L1، miRNA-145، سرطان پِتان

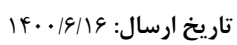

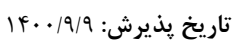

* نويسنده مسئول: mazizi528@gmail.com 
مثال، ملانوم و سرطان ريه نشان داده است. مولكولهاى

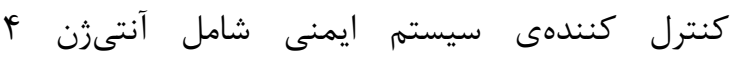

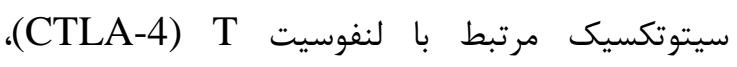
يروتئين ا مرى برنامهريزى شده سلول و كيرنده آن

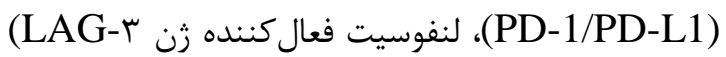
3 و ايمونوكلوبولين موسين -r سلول TIM-3) T

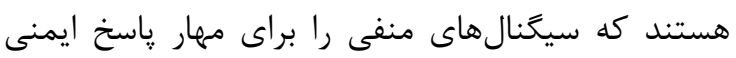

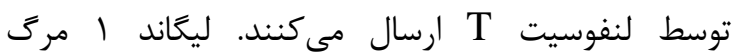
برنامهريزى شده (PD-L1) نوعى كليكويروتئين غشايى از خانواده ايمونو كلوبين نوع ا بوده كه به عنوان كيرندان

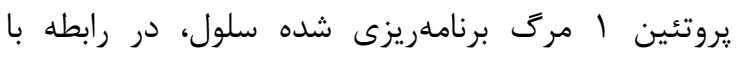

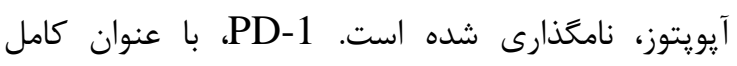
يروتئين ا مرى برنامهريزىشده سلول Programmed) cell death protein 1) شناخته مىشود، يك يروتئين سطحى سلولهاى T است

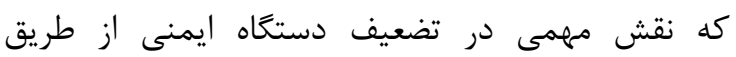
سركوب فعاليتهاى التهابى لنفوسيتهاىT ايفا مى كند. PD-1 PD-1 LPD-L1

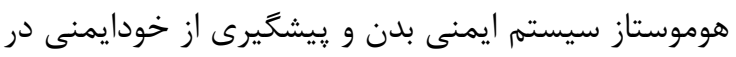

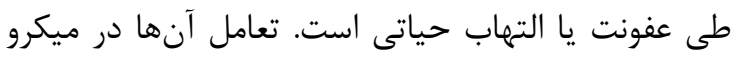

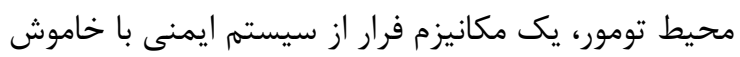
كردن سلولهاى T سيتوتوكسيك براى سلولهاى تومور

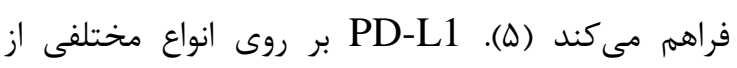
تومورها بيان و موجب بيشبرد رشد تومور مىشود (\&). در شرايط فيزيولوزيك، mRNA PD-L1 در بافتهاى مختلف بيان مى شود، اما يروتئين PD-L1 تنها در جند بافت مانند لوزهها و كسر كوجكى از سلولهاى ماكروفازها در ريه، كبد و جفت يافت مى شود كه اين نشاندهنده تنظيمات يس از رونويسى در mRNA PD-L1 ديد است PD-L1 در نمونههاى بافتهاى مختلف مانند

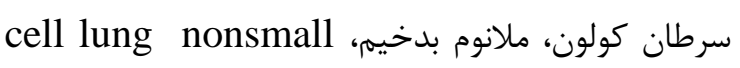
cancer (NCLC) مرى مطالعه شده است. بيان PD-L1 با اندازه بزرگى
موتاسيونهاى متعدد درون زنوم سلولهاى بافتهاى سرطانى يافت مىشوند، در نتيجه سرطانها جزو بيمارىهاى زنتيكى محسوب مى شوند. از طرف ديخر تنها

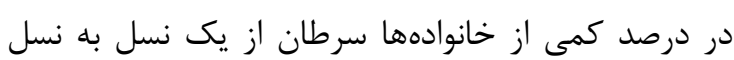
ديغر به صورت جهش تك رنى منى منتقل مى شود، بيشتر

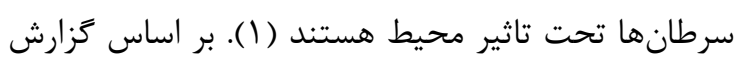
GLOBOCAN سرطانهاى شايع در جهان قرار دارد. اين بيمارى،

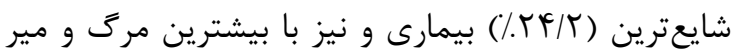
ناشى از سرطان در بين زنان (ه|/\%) است. در حالى كه ميزان مرك و مير ناشى از ساير سرطانها در مناطق

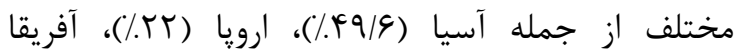

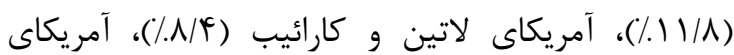

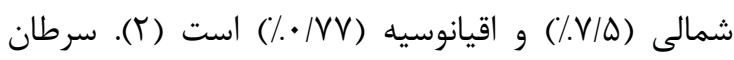
يستان، رشد مهار نشده سلولهاى غيرطبيعى است كه در بافتهاى مختلف يستان مانند مجارى انتقال دهنده شير، بافت توليد كننده شير و يا در بافت غير غددى رخ مى دهد (ז). در سالهاى اخير، درمان سرطان پِّتان پِيشرفت قابل ملاحظهاى داشته است، كه منجر به توسعه درمانهاى فردى و هدفمند و افزايش طول عمر شده است. با اين حال، هنوز نياز به تزينههاى درمانى جديد براى بيمارىهاى تهاجمى كه فاقد تزينههاى درمانى

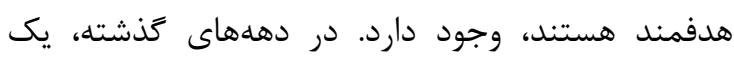
درمان جديد كه از سيستم ايمنى بدن براى درمان سرطان

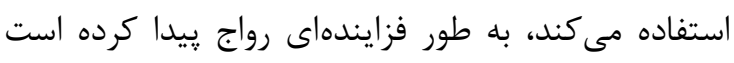

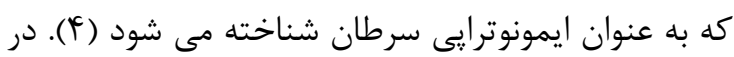
اين زمينه، تحولات اخير در ايمونوترايى اين اميد را ايجاد كرده است كه اين نوع درمان ممكن است در سرطان ״ستان موثر باشد. سركوبكندههاى محيطى سيستم ايمنى تومور، يكى از شش ويزگى بيولوزيكى متمايز است كه باعث رشد و متاستاز تومور مى شود. در حال حاضر بـ

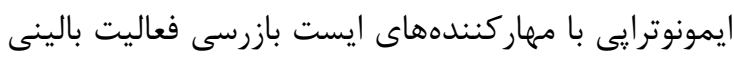

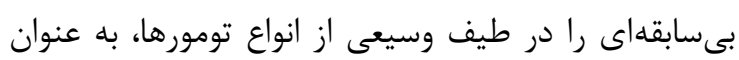


سلولى دخيل هستند؛ از اينرو، افزايش بيان آنها به

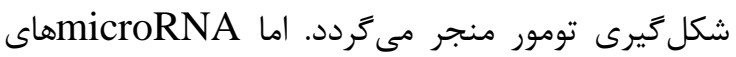

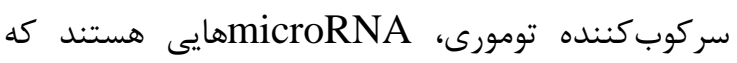
سطح بيان انكوزنهاى دخيل در سيكل سلولى و آيويتوز را كاهش مىدهند و لذا كاهش آنها سبب بروز تومور مى كردد (F) ( ). ايست و بازرسى ايمنى و ليكاندهاى آنها را تنظيم

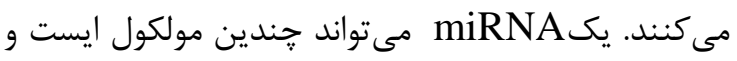
بازرسى را هدف قرار دهد. از سوى ديخر مولكولهاى

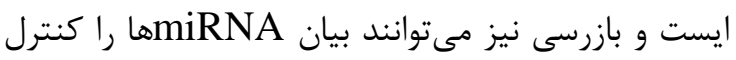

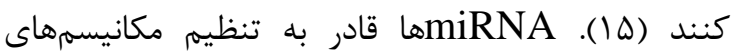
مولكولى در مسير سيخنالينگ PD-1/PD-L1 مىباشند.

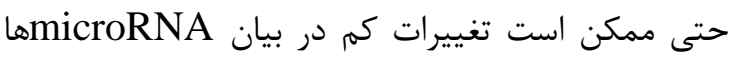

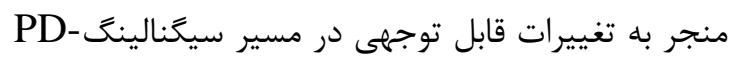

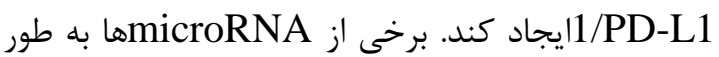

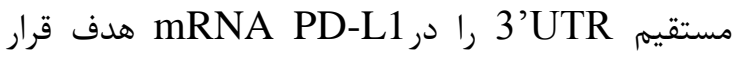
مى دهند و برخى ديخر به طور غيرمستقيم توسط سيخنال

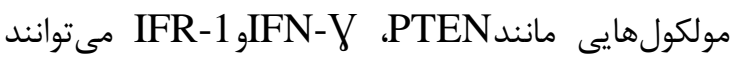

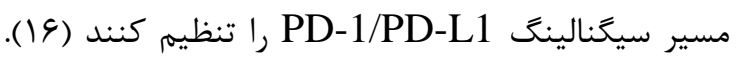
جهش تك نوكلئوتيدى در 3'UTR PD-L1 مىتواند منجر به بيان بيش از حد PDL-1 شود. اين رويداد ناشى دري از اختلال در جفتشدكى صحيح بين 3'UTR PD-L1

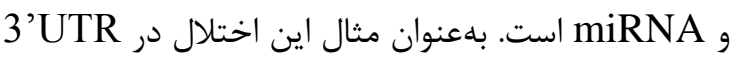

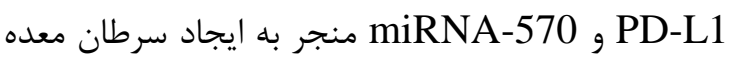
با فنوتيب تهاجمى شده است. تعامل بين MiRNAs و 3’UTR PD-L1 3’UTR PD-L1 است و اين نوع جهش يكى از مكانيسمهايى است كه سلولهاى تومورى توسط آن

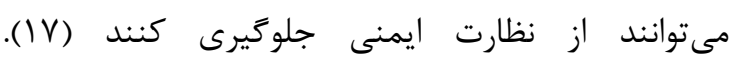
miRNA-145 بر روى كروموزوم شماره ه، كه يك ائى ناحيه شكننده در زنوم است، واقع شده است. اين

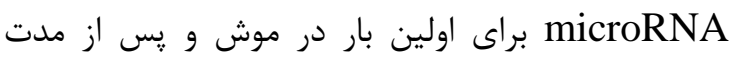

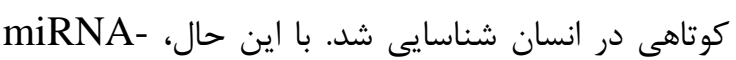

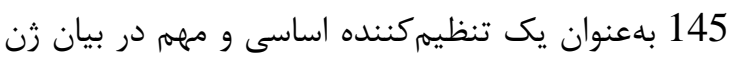

تومور، بالا بودن درجه سرطان، تكثير زياد سلول سرطانى،

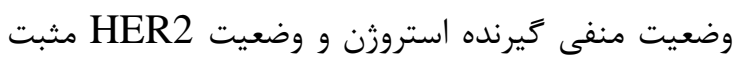

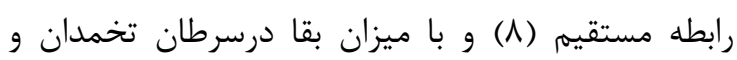

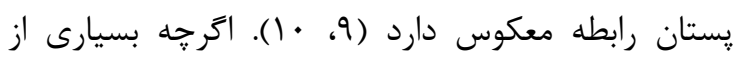

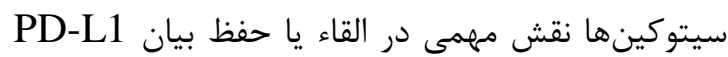

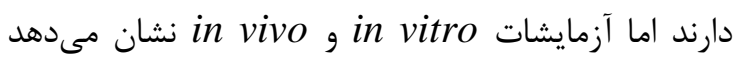
كه بيان بروتئين PD-L1 در سلولهاى ارائه دهنده آنتى زن (APCs)، لنفوسيتهاى T و سلولهاى سرطانى به شدت به وجود اينترفرون گاما (IFN-Y) بستخى دارد. سلولهاى التهابى، به ويزه لنفوسيتهاى فعال، اغلب به

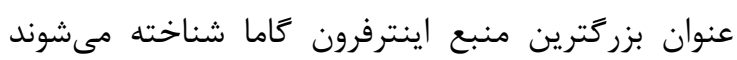

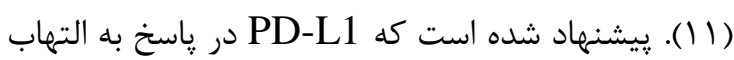

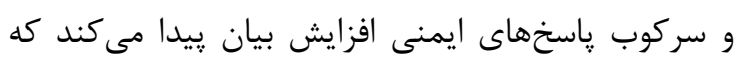

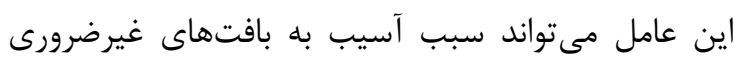
شود. سلولهاى تومورى از اين مكانيسم براى فرار از سيستم ايمنى استفاده مى كنند (r) (I ). از آنجايى كه عملكرد miRNAها در تنظيم فرآيندهاى زيستى حياتى ضرورى است به نظر مىرسد الها با ييشآكهى، ييشرفت و علت بروز سرطان در ارتباطند.

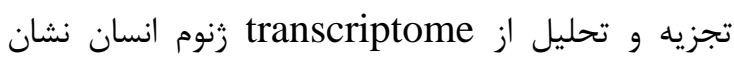

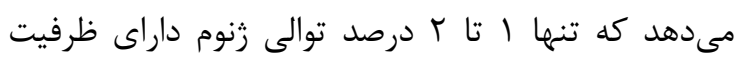
كدكذارى يروتئين است كه نشان مى مهدهد تعداد زيادى

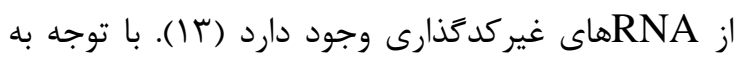

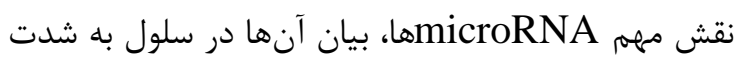
كنترل شده بوده و هرگونه تغيير در بيان آنها با ايجاد شرايط پاتولوزيكى مختلف از جمله ايجاد سرطان در ارتباط مىباشد. مطالعات متعدد نشان داده است كه در بافتهاى طبيعى بيان miRNA متفاوت از بافتهاى تومورى بوده و نيز در بين انواع تومورها متفاوت است. أهicroRNA سركوبكننده تومورى (Ts-miR) و هم به به صورت

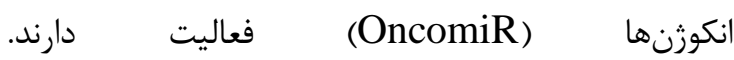
microRNA سركوبكننده تومورى و يا زنهايى مىشوند كه در تمايز 


\section{مواد و روشها}

ييشبينى بيوانفور ماتيك

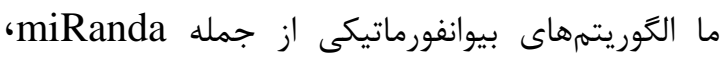
PicTar بالقوه هدف miRNA-145 ادغام كردهايم. طبق تجزيه و تحليل ييشبينى شده، در PD-L1'UTR زن Pن محل اتصال احتمالى miRNA-145 در نظر گرفته شده 3’UTR ،miRNA-145 است. براى تأييد تعامل هدف

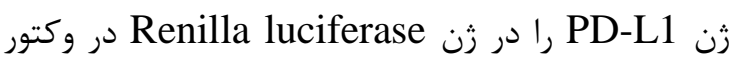
psiCHECKTM-2 miRNA scrambled miRNA-145 يمزمان بان (بهمم ريخته) با غلظت نهايى . ․ نانومولار در سلولهاى MDA-MB231 و BT549 و MCF7 ترانسفكت شد.

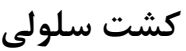

براى انجام اين مطالعه از سه رده سلولى سرطان يُتان

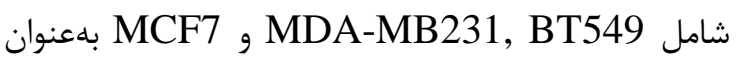
ردههايى با افزايش بيان PD-L1 و رون رده سلولى بCF10a

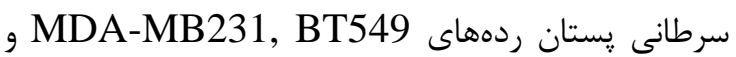
از مركز ذخاير زنتيكى و زيستى ايران MCF7 Biological Resources center, IBRC, و رده سلولى غيرسرطانى يستان Tehran, Iran) MCF10a

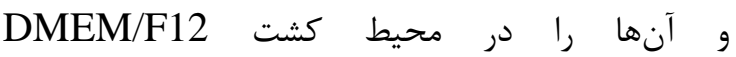
Fetal Bovine \% غنى شده با (Gibco,USA) Serum (FBS) (Gibco,USA)

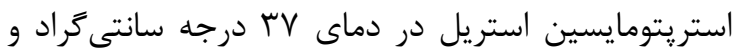

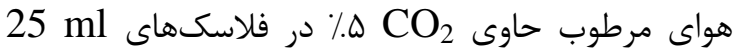
كشت داده شدند. نكات اخلاقى كار با رده سلول سرطانى اين يروزه تحت نظارت كميته اخلاق انستيتو پِاستور ايران انجام شده است و همه مراحل اخلاقى در آن رعايت شده است. نكات اخلاقى مربوط به رده سلولهاى انسانى توسط مركز بانك سلولى انستيتو ياستور از جمله وجود فرم
مطرح است (1)). S.Y. Cui و همكارانش در سال

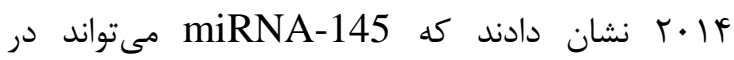
مجموعهاى از عملكردهاى تومورزا شامل تنظيم تكثير

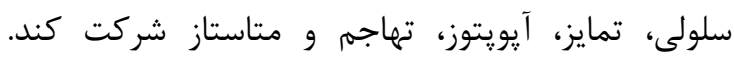
همجنين در سرطانهايى از جمله پِتان، كولون، كبد،

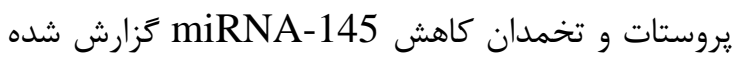
است (19). Yanling Ding و همكارانش در سال

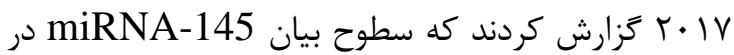
بافت سرطان يستان در مقايسه با بافت طبيعى مجاور

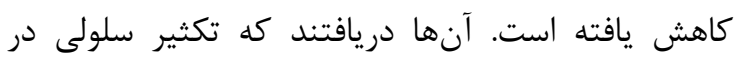

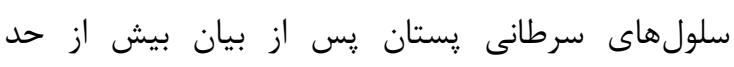

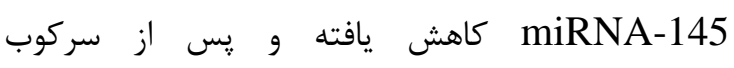
miRNA-145 افزايش يافته است (• (؟). در اين مطالعه هدف ما، با توجه به نقش احتمالى سركوبكنندگى تومور miRNA-145 در سرطان يستان، از طريق تجزيه و تحليل ارتباط بين بيان

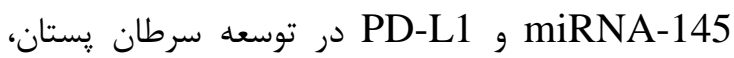
مشاركت miRNA-145 در مهار بيشرفت اين بيمارى

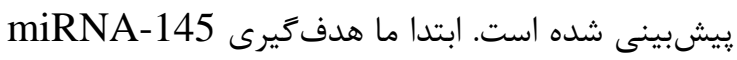

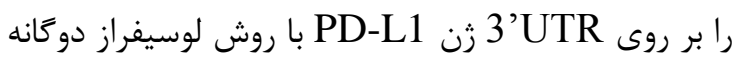
تأييد كرديه. نتايج ما نشان داد كه بيان miRNA-145 رون در رده هاى سلولى سرطان يستان در مقايسه با سلولهاى

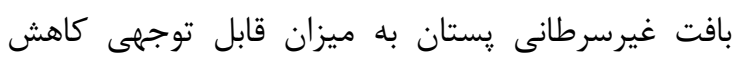

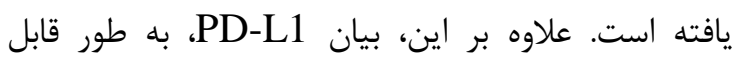
توجهى در ردهاى سلولى سرطان يستان افزايش يافته و يس از افزايش بيان miRNA-145 در ردههاى سلولى سرطان پستان، كاهش بيان PD-L1 را نشان داديم.

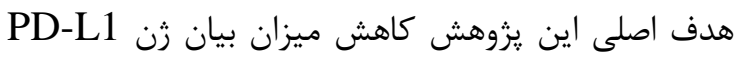

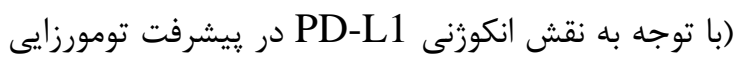

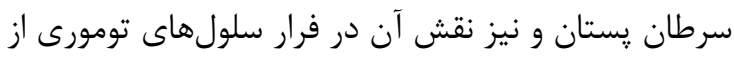

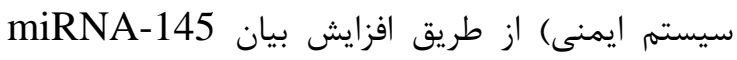
بهعنوان سركوبخر تومور در سه رده سلولى سرطان يستان 
POLARstar Omega (BMG منتشره توسط دستگاه LABTECH, Germany)

استخراج RNA سنتز Real time و qRT- PCR به منظور تغيير بيان زن PD-L1 توسط ورود-miRNA

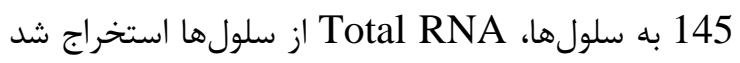
(توسط كيت استخراج Qiagen, Germany, RNA). غلظت RNA توسط دستخاه NanoDROP اندازهخيرى شد و با تعيين نسبت جذب در 260 و A280 كيفيت مورد ارزيابى قرار كرفت. سنتز RNA

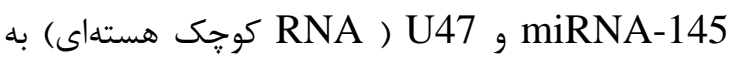
stem loop عنوان كنترل داخلى توسط يرايمرهاى (جدول () انجام شد (توسط كيت Takara, japan). Real Time PCR و MiRNA-145 به وسيله دستغاه Step one plus و يرايمرهاى اختصاصى master mix biofact miRNA-145 و U47 (جدول () انجام شد. همجنين براى بررسى ميزان بيان PD-L1 در سلولهاى رده سرطانى و غيرسرطانى يستان نيز از يرايمرهاى اختصاصى ئى PD-L1 خانهدار (House Keeping Gene) استفاده شد. واكنشها به صورت دوتايى بود و ميانگين

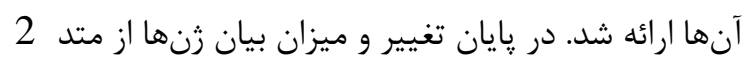
Fزارش Fold change استفاده شد و ميزان كرديد.

$$
\text { آناليز آمارى }
$$

SPSS V.22 Inc., نسخه r SPSS نرماز Chicago, IL

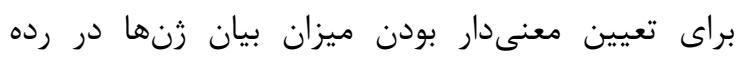

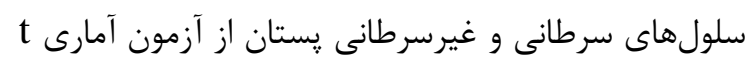

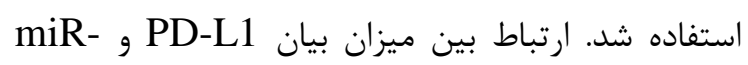
145 با روش ANOVA سنجيده شد. براى رسم نمودار از نرمافزار GraphPad prism V.8 استفاده شد.
رضايت آكاهانه از فرد بيمار جهت كَرفتن نمونه سلولى نكات اخلى اوليه، نكات اخلاقى در رابطه با هركونه دستورى زنتيكى و

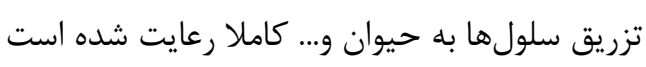
microRNA ترانسفكت miRNA Scrambled Ambion (Life Life, AM17102) است. سلولها يك روز قبل از ترانسفكت كشت داده شدند. طبق يروتكل كيت، در يك ميكروتيوب استريل وكتور

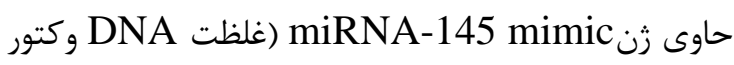

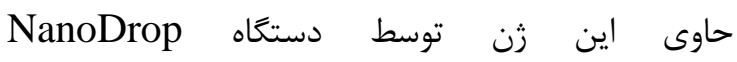
اندازهخيرى (ThermoScientific, 2000c, USA) ترديد)، محلول Hyperfect Transfection Reagent اضافه شد و در يك ميكروتيوب (Qiagen, Germany) ديخر scrambled miRNA با غلظت نهايى 100nM به Attraccent Transfection Reagent، به صورت جداگانه، اضافه و سيس به سلولها ترانسفكت شدند.

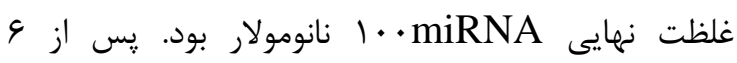

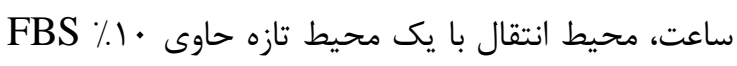

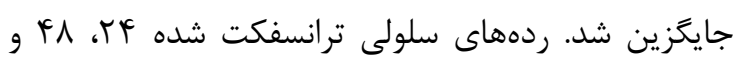

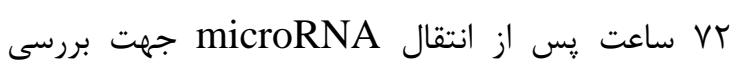
تاثير بر ميزان بيان PD-L1 برداشت شدند. آزمون سنجش دو آنانه لوسيفراز از روش سنجش دوكانه لوسيفراز براى تأييد تعامل

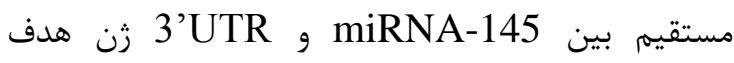
3'UTR استفاده شد. در انجام اين آزمايش، براى تكثير

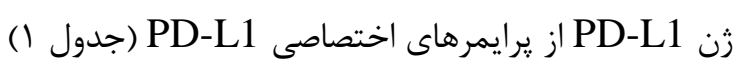

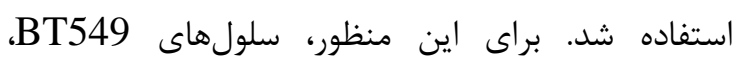
و MDA-MB231 حاوى 3D'UTR زن PD-L1 به ميزان يك ميكروكرم و miRNA-145(mimic) or scrambled نهايى · · انانومولار به صورت همزمان ترنسفكت شدند. طبق دستورالعمل كيت لوسيفراز (Promega, USA)،

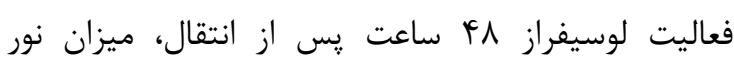


جدول ا: توالى برايمر هاى استفاده شده جهت انجام PCR و Real Time

\begin{tabular}{llc}
\hline Gene & \multicolumn{1}{c}{ Sequence of Oligonucelotides from 5' to 3' for PCR Analysis } & Product \\
\hline PD-L1 & $\begin{array}{l}\text { Forward: CCGCTCGAGCAGATACACATTTGGAGGAGA } \\
\text { Reverse: ATAAGAATGCGGCCGCTGTGCAGGATTCAAAAGCAT } \\
\text { Gene }\end{array}$ & \multicolumn{1}{c}{ Sequence of Oligonucelotides from 5' to 3' for Real Time-PCR Analysis } \\
PD-L1 & $\begin{array}{l}\text { Forward: GTGATCCGCTGCATGATCAG } \\
\text { Reverse: GGTAGCCCTCAGCCTGACATG }\end{array}$ & Product \\
\hline GAPDH & $\begin{array}{l}\text { Forward: GAAAGCCTGCCGGTGACTAA } \\
\text { Reverse: GCGCCCAATACGACCAAATC }\end{array}$ & $151 \mathrm{bp}$ \\
\hline \multirow{2}{*}{ miR-145-5p } & $\begin{array}{l}\text { Forward: GTCCAGTTTCCCAGGAATCCC } \\
\text { Reverse: AGACTGCACCTGTCCGG }\end{array}$ & $152 \mathrm{bp}$ \\
\hline $\begin{array}{l}\text { Stem loop } \\
\text { miR-145-5P }\end{array}$ & CAATTAGACTACACCTGTCCGGTCCCTGCGTCCTGTAGTCTAATTGAGGGAT & $64 \mathrm{bp}$ \\
\hline
\end{tabular}

داده شده است. لازم به ذكر است كه اين اطلاعات از يايكاه يافتهها

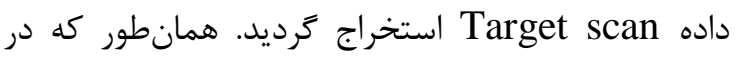
شكل BiRNA-145 نشان داده شده است، مقايسه با اليكونو كلئوتيد بهم ريخته، فعاليت لوسيفراز را به miRNA- ميزان قابل توجهى كاهش ميدهد. انتقال

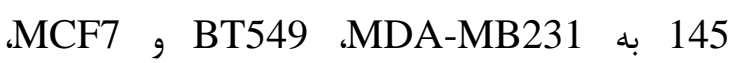

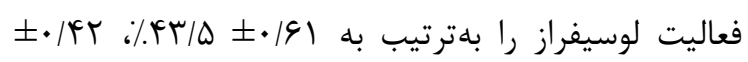

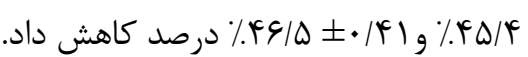
معرفى miRNA-145 بهعنوان miRNA سر كوبكر بيان انكوزن PD-L1 در سلولهاى رده سرطان يستان براى تأييد اين فرضيه كه بيان بيش از حد - miRNA

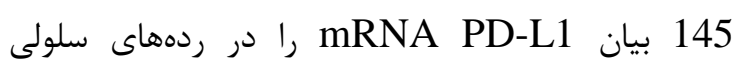
سرطان يستان كاهش مىدهد،

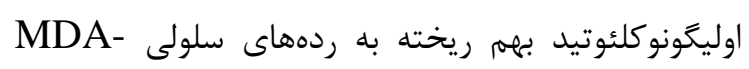
BT549 MB231 ترانسفكت، ميزان بيان PD-L1 (شكل A جهت تاييد طول قطعه تكثير يافته، محصول نهايى Real بر روى زل آكارز ؟ Time PCR همجنين ميزان بيان miRNA-145 در سلولهاى رده

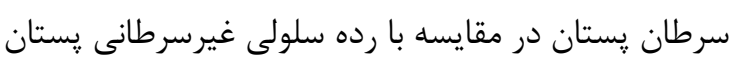
ب به صورت معنادارى كاهش يافته بود،

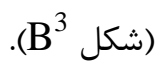

نتايج حاصل از كلون كردن قطعه 3'UTR زن L1 در وكتور psi-check2 توالى محدود به آنزيمهاى محدود كننده Not1/Xho1 در

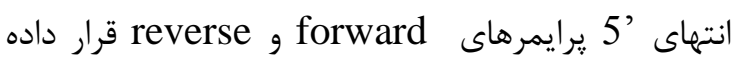

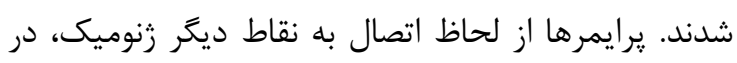
NCBI Blast كه يرايمرها داراى اتصال اختصاصى به توالى مورد نظر

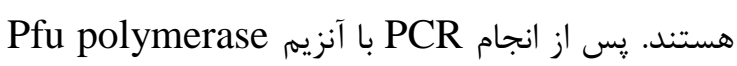

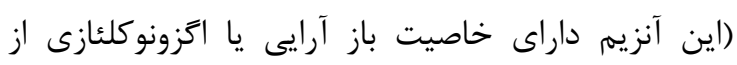
انتهاى 'ها' 'ب است و قطعه توليد شده توسط اين آنزيم داراى خطاى همانند سازى كمترى مىباشد و محصول

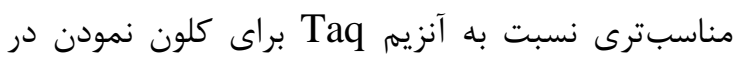

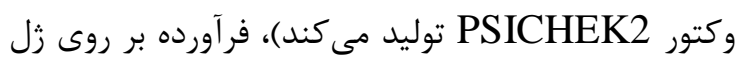
الكتروفورز ران و تائيد شد.

ييشبينى miRNA-145 بهعنوان miRNA هدف كيرنده 3'UTR زن PD-L1 توسط يايعًاههاى داده و ابزارهاى بيوانفورماتيك

در اين مطالعه با استفاده از پايكاههاى داده و ابزارهاى

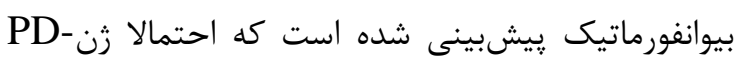

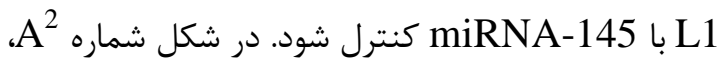

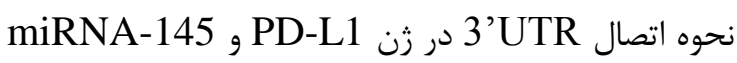

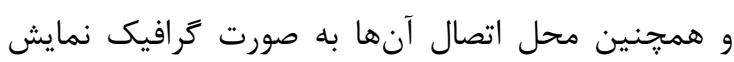


9.3\% 0.547 25.9\% و در MCF7 0.541

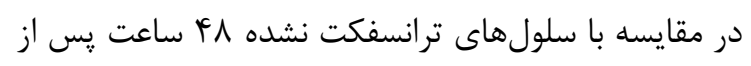

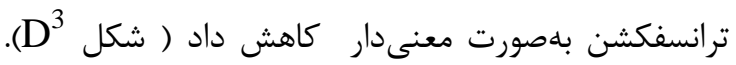

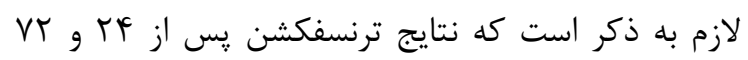

$$
\text { ساعت معنى دار نبود. }
$$

بين كاهش بيان miRNA-145 و افزايش بيان PD-L1 در سلولهاى سرطان پستان رابطه مستقيم وجود دارد (شكل روش qRT- PCR اندازهگيرى شد. بيان افزايش يافته ا ا. miRNA-145 MDA-MB231

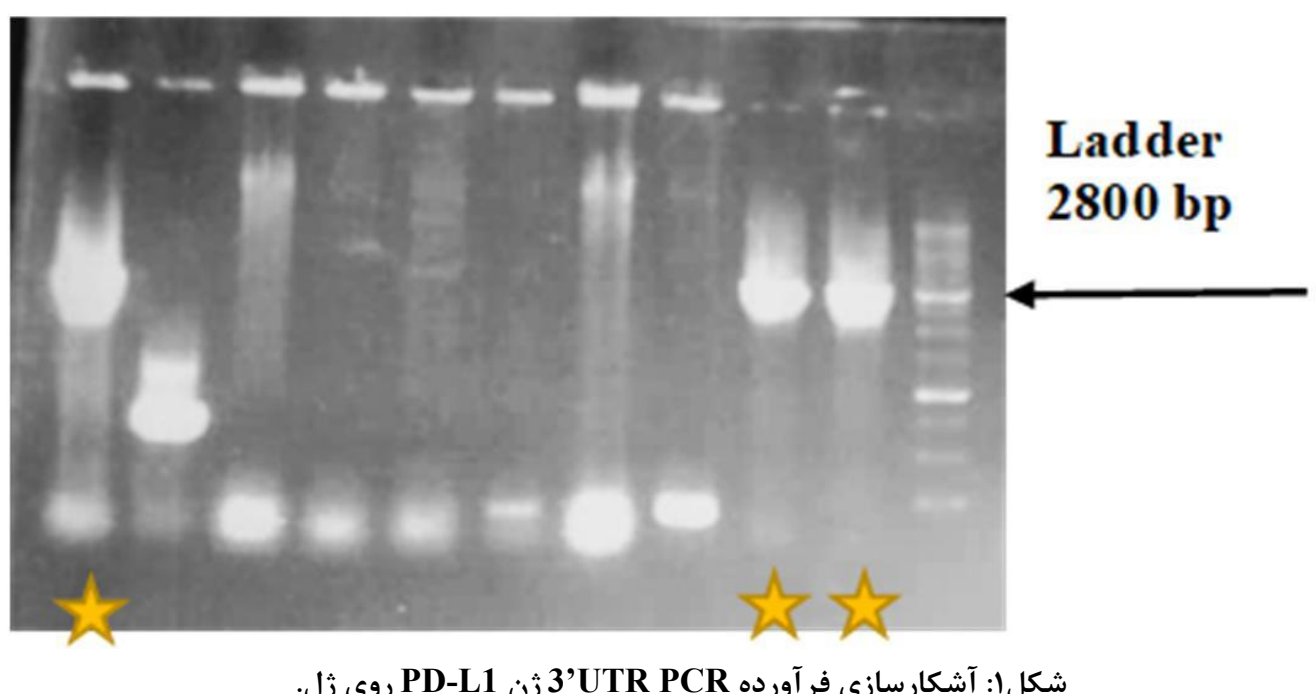

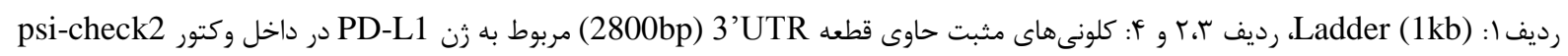

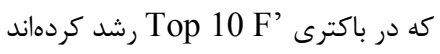

A

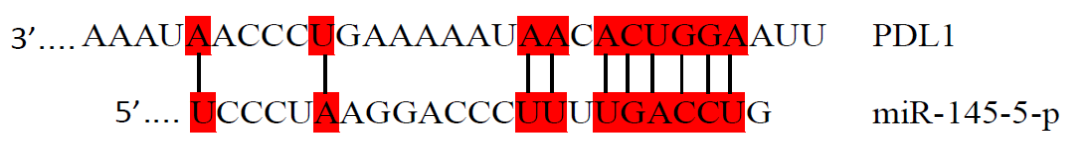

B

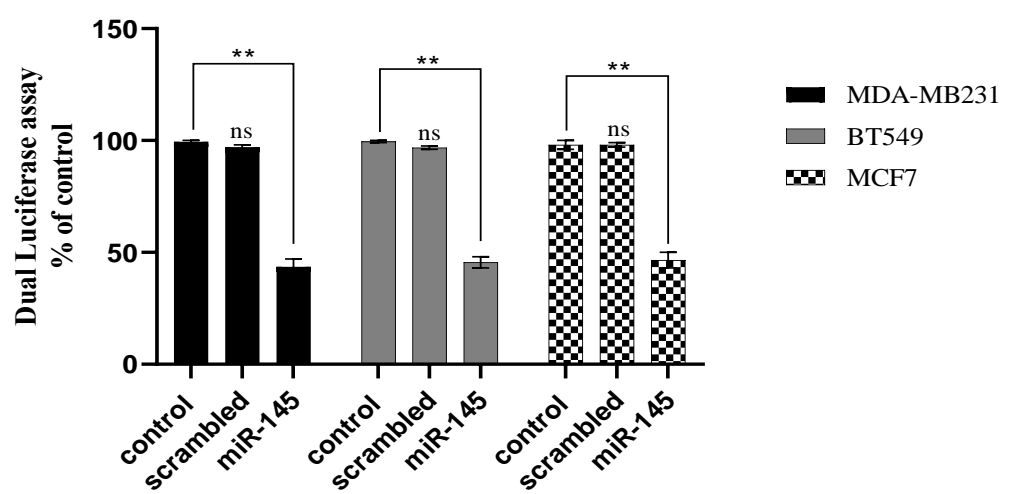

شكل ז: هدف َيرى PD-L1 توسط miRNA-145 در سلولهاى رده سرطان بستان.

miRNA-145 A

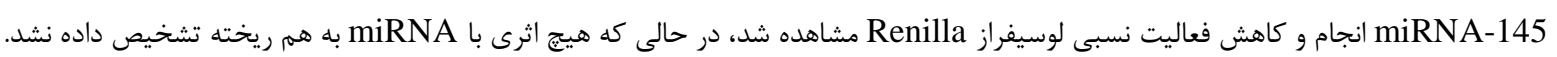

**p <.01; ns = nonsignificant 
A
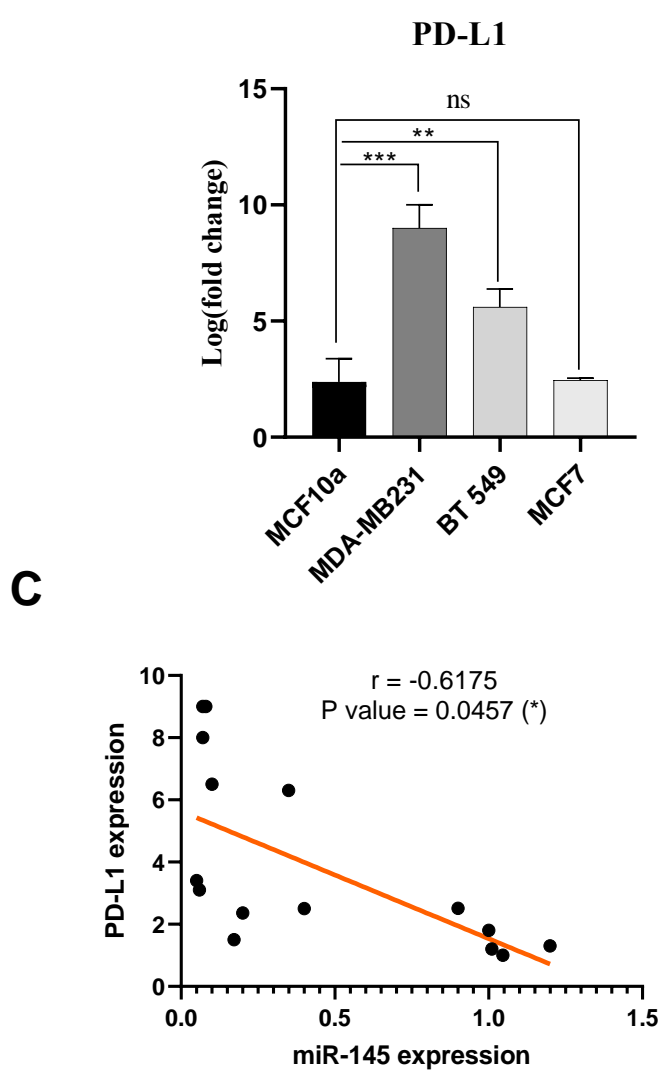

B

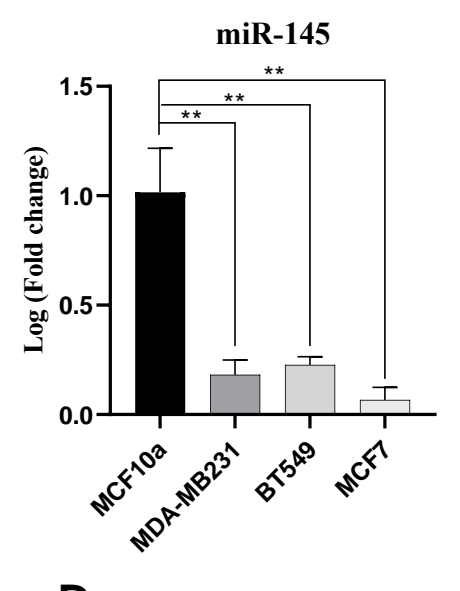

D

PD-L1

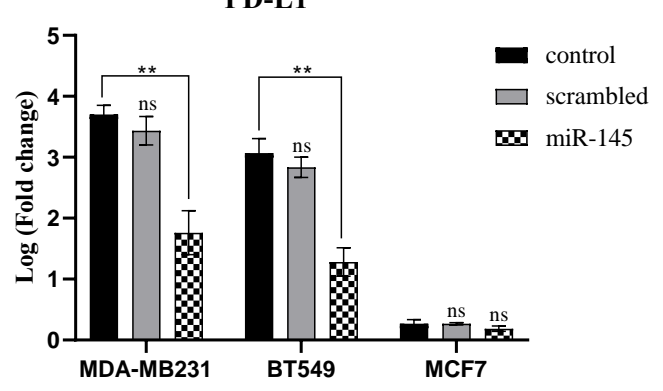

$$
\text { شكل r: بيان PD-L1 و miRNA-145 در سلولهاى رده سرطان بستان. }
$$

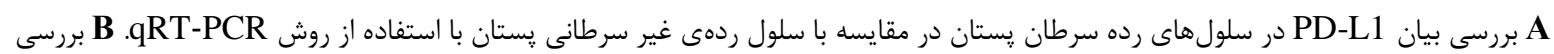

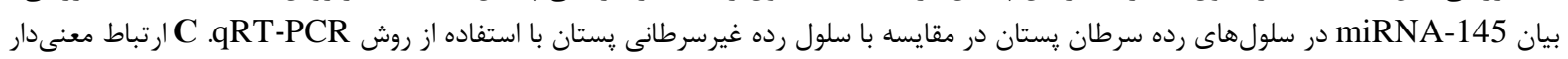

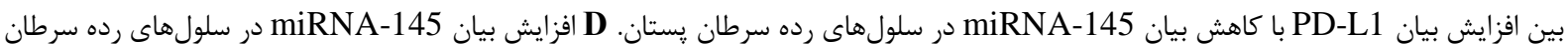

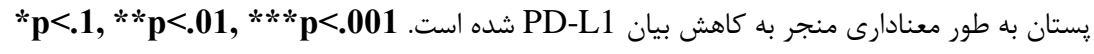

از لنفوسيتهاى نفوذكننده تومور مثبت بودند. در نتيجه

انسداد اين مسير، آن را به يك هدف درمانى ارزشمند

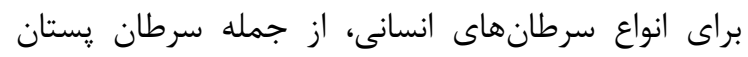
تبديل مى كند.

ارتباط بين كاهش ميزان آيإِتوز و تكثير سلول T و فرار

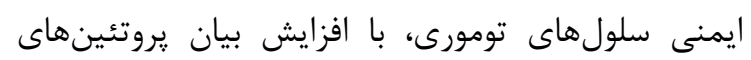

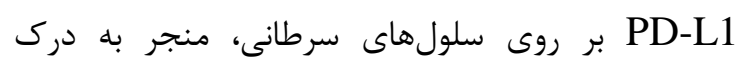

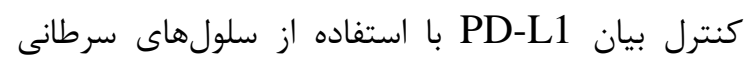

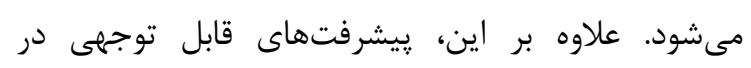

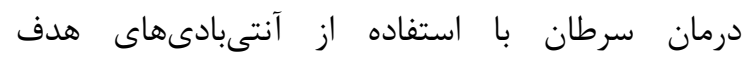
Pembrolizumab مانند، كه مورد PD-1/PD-L1
سرطانزايى گِستان، فرآيندى است كه شامل اختلال در تنظيم زنهاى سركوب كننده تومور و آنكوزنها است

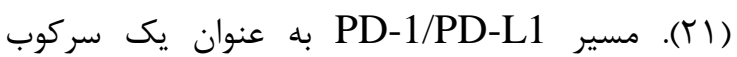
كننده سيستم ايمنى مههم است و در طيف وسيعى از سرطان هاى انسان از جمله سرطان يستان تنظيم مىشود

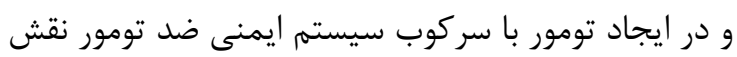

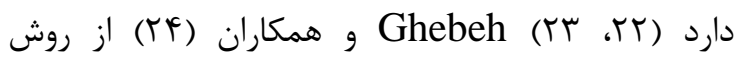
PD- ايمونوهيستوشيمى براى تشخيص بيان يروتئينهاى

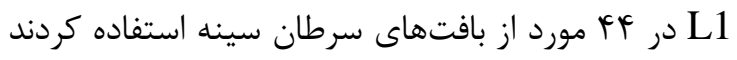

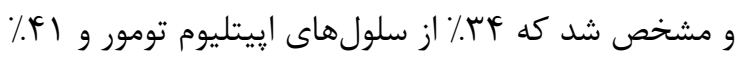


كاهش بيان داشته است، miRNA-145 است (19). كاهش بيان اين miRNA در سرطان ريه منجر به دان افزايش تكثير و متاستاز و از طرف ديكر كاهش ميزان

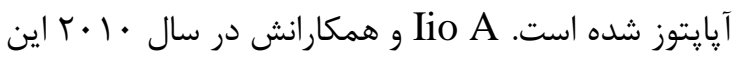

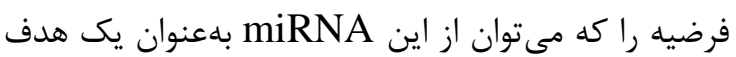
درمانى در سرطان ريه استفاده كرد، مطرح نمودند. در miRNA Replacement اينجا روش جديدى به نام مطرح مىشود كه در اين روش توسط وكتور therapy

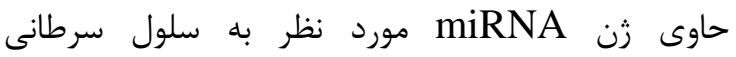
miRNA ترانسفكت مىشود. بدين ترتيب مىتوان بيان مورد نظر را در سلول سرطانى به سطح طبيعى بازكرداند و

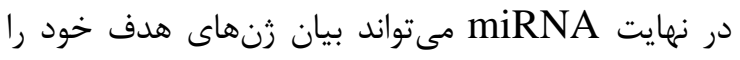
تنظيم كند. طبيعى بودن تومورسايرسورها، يايدارى و

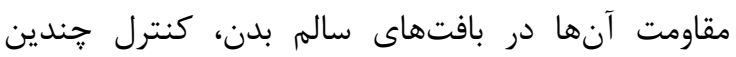
مسير ايجاد سرطان و تعداد زيادى انكوزن از جمله مزاياى اين روش است، علاوه بر اين، به علت وجود تعداد فراوان

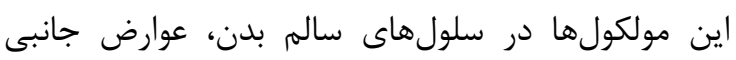

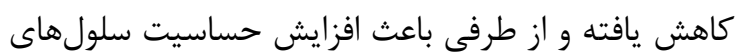

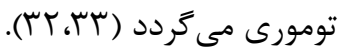

در راستاى تحقيقات ما، Xinsheng Peng

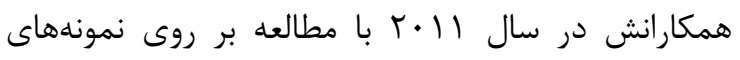
سرطان يروستات، بيان كردند كه ارتباط معنادارى ميان

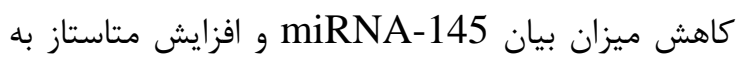
استخوان در نمونههاى بيماران مورد مطالعه وجود دارد. اين كروه كاهش ميزان متاستاز را در سلولهاى رده سرطان يروستات پِ از ترانسفكت miRNA-145 به

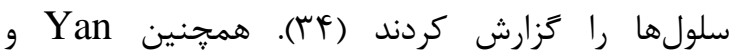

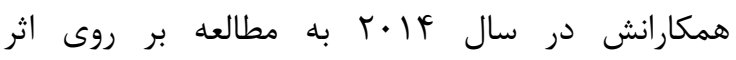
miRNA-145 بر روى رسيتور erbb3 در سلولهاى سرطان پِتان در شرايط in-vivo و

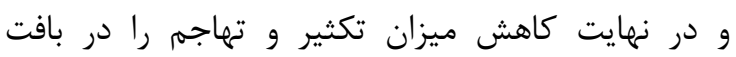

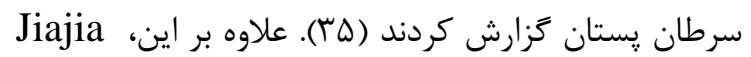

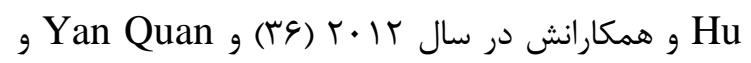

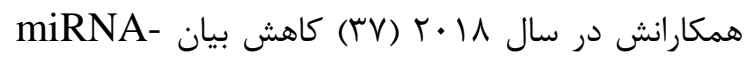

تائيد سازمان غذا و داروى آمريكا (FDA) است، در

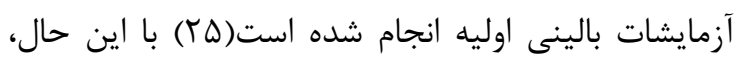
براى اكثر بيمارانى كه از اين شيوه درمانى استفاده

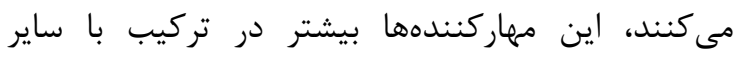
درمانها از جمله شيمىدمانى تجويز مىشوند (ع)). با معائ اين وجود، مطالعات زيادى نشان داده است كه بسيارى از عوامل شيمىدرمانى رايج، از جمله Fluorouracil-5 و Paclitaxel منجر به افزايش بيان PD-L1 مىشوند. اين قديده، به نوبه خود، واكنش سلولهاى T ضد تومور با واسطه سلول را كاهش داده و منجر به افزايش فرار

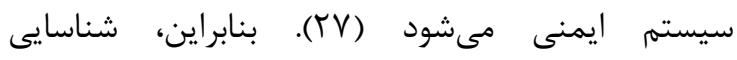
PD- مكانيسمهاى مولكولى دخيل در تنظيم مستوني

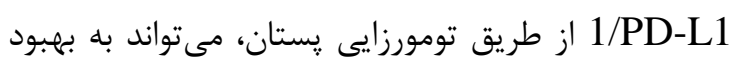

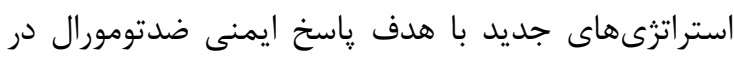
مقابل سرطان يستان كمك كند. در سرطان يستان، با توجه به تشخيص و نظارت بر ياسخ بيمار نسبت به درمان، كه اين امر نيازمند وجود بيوماركرهاى تشخيصى مناسب است، مىتوان به طور موثر

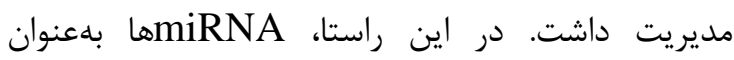
بيوماركر و نيز يك عامل درونى مورد توجه قرار كرفتهاند

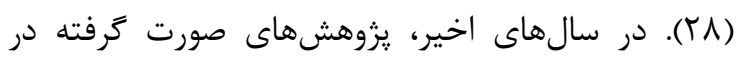

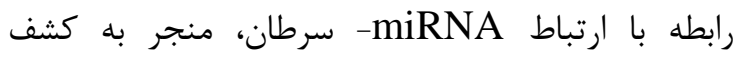

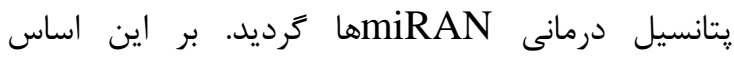
مىتوان ادعا نمود كه دهiRAN به عنوان اهداف فارماكولوزيك، نسبت به درمانهاى حال حاضر، اثراتى

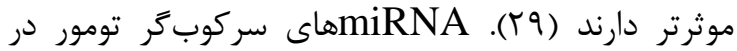

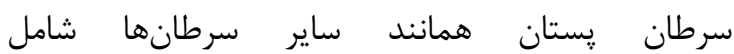

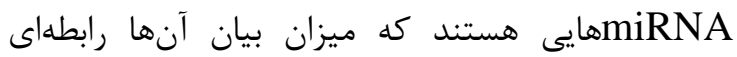

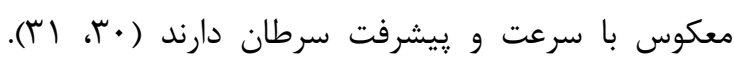
دستيابى به روشهاى كار آمد براى افزايش بيان اين نوع از

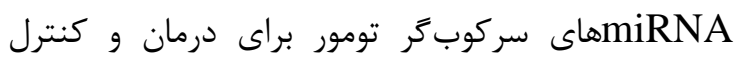
سرطان و يا عوارض ناشى از اين بيمارى، مورد توجه است.

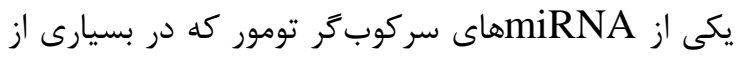
سرطانها از جمله سرطان تخمدان، يستان، ريه و كولون 
ميزان بيان PD-L1 ندارد اين امكان وجود دارد كه با

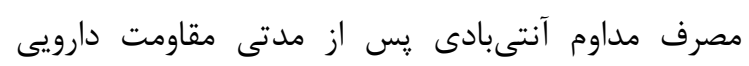

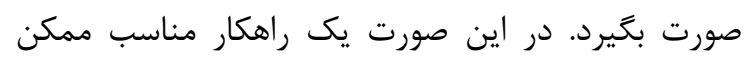
است استفاده از عواملى باشد كه در سطح بيان زن، ميزان

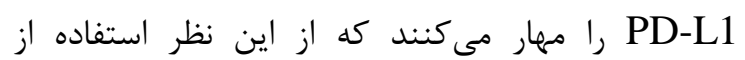

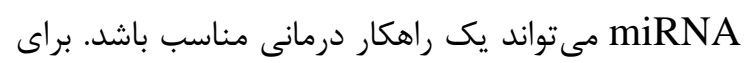

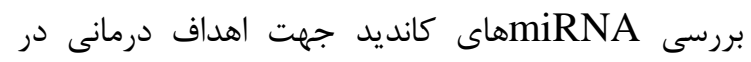
ارتباط با PD-L1 و آشكارسازى مكانيسمهاى اساسى تنظيم شده توسط اين miRNAها، و همجنين براى اطمينان از نقش عملكردى آنها در سركوب يِيشرفت

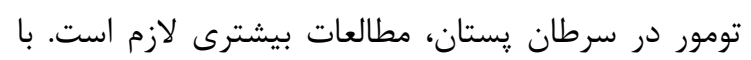

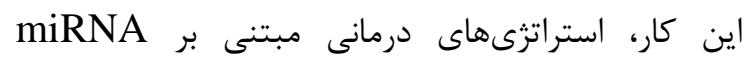
مىتواند با درمانهاى متداول، مانند شيمىدرمانى، درمان

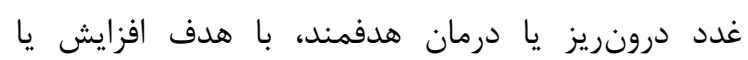
همافزايى اثرات ضد سرطانى با كاهش سميت و بهببود ميزان بقاى كلى بيماران مبتلا به سرطان يستان تركيب إنى

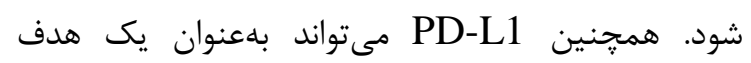

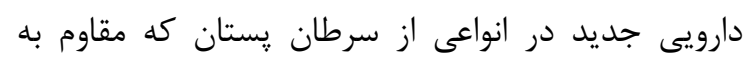

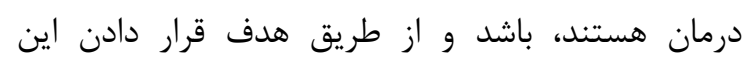
تاركت، سيستم ايمنى با شدت و قدرت بيشترى از تكثير بى رويه و تهاجم سلول هاى سرطانى ممانعت مى كند.

\section{نتيجهكيرى}

miRNA- يافتهاى ما نشان ميدهد كه ميزان بيان

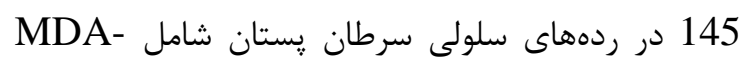
در مقايسه با رده سلولى كنترل MB231, BT549

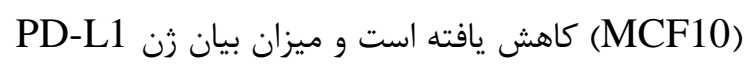
افزايش بيان يافته است. همجنين سيستم لوسيفرازى نشان داد كه mRNA زن PD-L1 هدف مستقيم miRNA- است. از طرفى افزايش بيان miRNA-145 145 در ردههاى سلولى سرطان پستان منجر به كاهش إن

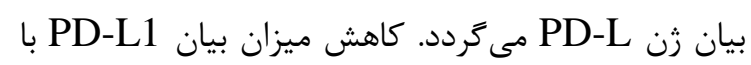

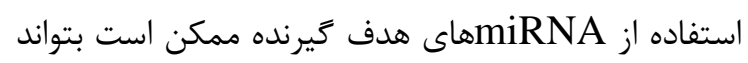

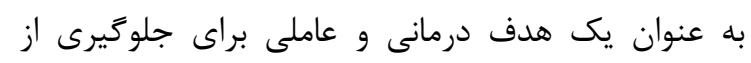

145 را در بافت سرطانى پستان و نيز در سلولهاى رده

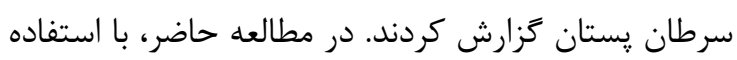

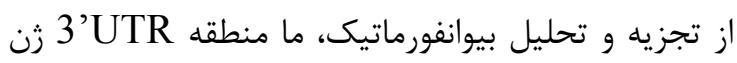

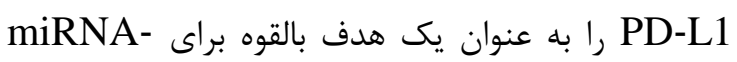

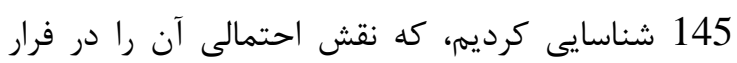
سلولهاى تومورى از سيستم ايمنى نشان مى دهد. متعاقباً،

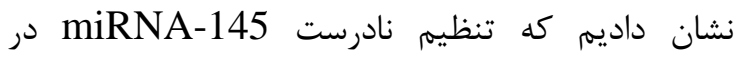
سلولهاى رده سرطان بستان با افزايش بيان PD-L1

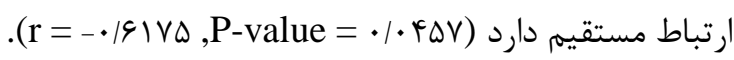
كه نشان ميىدهد miRNA-145 ممكن است در درد تنظيمات يس از رونويسى بيان PD-L1 نقش داشته

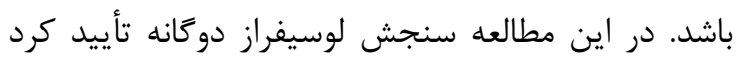

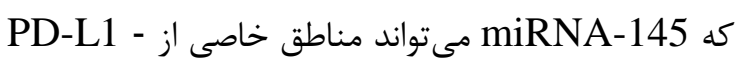

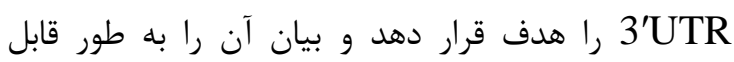
توجهى كاهش دهد (P<0.01). همجنين، نتايج بهدست

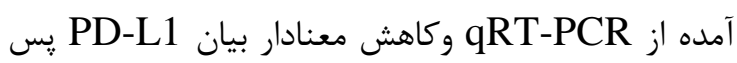

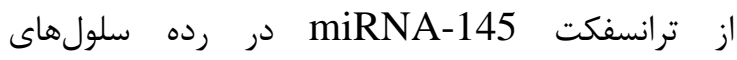
متاستاتيك سرطان پِتان (MDA-MB231,BT549)

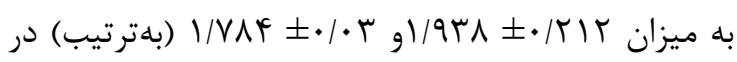

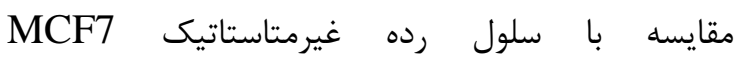

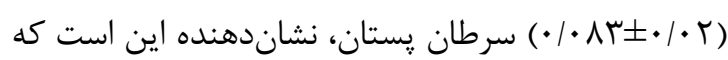
كاهش قابل توجه MiR-145 در افزايش ميزان Pن

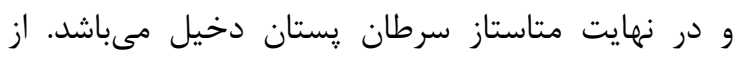

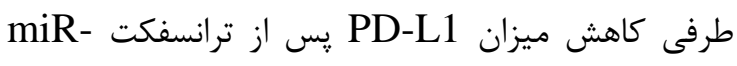
145، صحيح بودن ترانسفكت و داشتن عملكرد قابل قبول جهت افزايش بيان زن تومورسايرسور miRNA- مىباشد. بر اساس اين مطالعه افزايش بيان تورسن

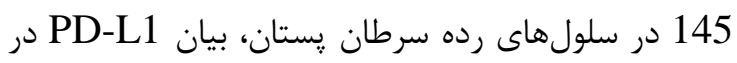

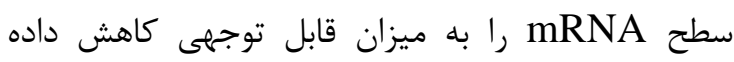

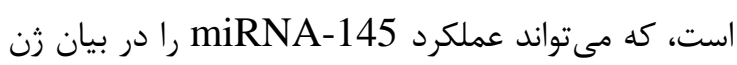
در سرطان پِّتان تعديل كند. در حال حاضر

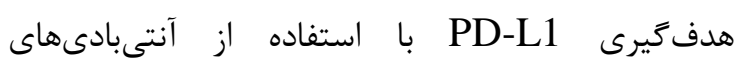
مونوكلونال يك راهكار درمانى تاييد شده براى سرطان

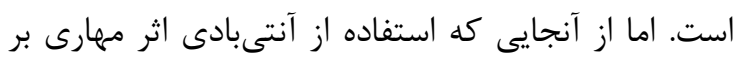


in عامل درمانى نياز به تحقيقات بيشتر از جمله آزمايشات vivo و بررسىهاى high throughput است.

$$
\text { تعارض منافع }
$$

\section{References}

1. Huang GL, Zhang XH, Guo GL, Huang KT, Yang KY, Shen X, You J, Hu XQ. Clinical significance of miR-21 expression in breast cancer: SYBR-Green I-based real-time RTPCR study of invasive ductal carcinoma. Oncology reports. 2009 Mar 1;21(3):673-9.

2. Bray F, Ferlay J, Soerjomataram I, Siegel RL, Torre LA, Jemal AJCacjfc. Global cancer statistics 2018: GLOBOCAN estimates of incidence and mortality worldwide for 36 cancers in 185 countries. 2018;68(6):394-424.

3. Hanahan D, Weinberg RA. The hallmarks of cancer. cell. 2000 Jan 7;100(1):57-70.

4. Yang YJTJoci. Cancer immunotherapy: harnessing the immune system to battle cancer. 2015;125(9):3335-7.

5. Horita H, Law A, Hong S, Middleton KJN. Identifying regulatory posttranslational modifications of PD-L1: a focus on monoubiquitinaton. 2017;19(4):346-53.

6. Xie Q-K, Zhao Y-J, Pan T, Lyu N, Mu L-W, Li S-L, et al. Programmed death ligand 1 as an indicator of pre-existing adaptive immune responses in human hepatocellular carcinoma. 2016;5(7):e1181252.

7. Parry RV, Chemnitz JM, Frauwirth KA, Lanfranco AR, Braunstein I, Kobayashi SV, et al. CTLA-4 and PD-1 receptors inhibit T-cell activation by distinct mechanisms. 2005;25(21):9543-53.

8. Sabatier R, Finetti P, Mamessier E, Adelaide J, Chaffanet M, Ali HR, et al. Prognostic and predictive value of PDL1 expression in breast cancer. 2015;6(7):5449.

9. Emens LA, Braiteh FS, Cassier P, Delord J-P, Eder JP, Fasso M, et al. Inhibition of PD-L1 by MPDL3280A leads to clinical activity in

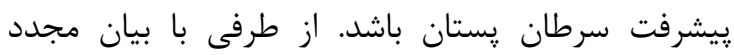

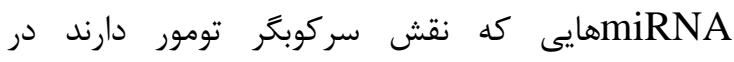

$$
\begin{aligned}
& \text { سلولهاى سرطانى مىتوان بيان بيش از حد انكوزنها را ران }
\end{aligned}
$$

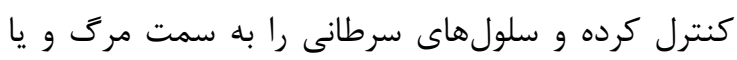

$$
\begin{aligned}
& \text { ييرى سوق داد. البته جهت كاربرد miRNA بهعنوان }
\end{aligned}
$$

patients with metastatic triple-negative breast cancer (TNBC). AACR; 2015.

10. Muenst S, Soysal S, Gao F, Obermann E, Oertli D, Gillanders WJBcr, et al. The presence of programmed death 1 (PD-1)positive tumor-infiltrating lymphocytes is associated with poor prognosis in human breast cancer. 2013;139(3):667-76.

11. Gu X, Wang Y, Xiang J, Chen Z, Wang L, Lu L, Qian S. Interferon- $\gamma$ triggers hepatic stellate cell-mediated immune regulation through MEK/ERK signaling pathway. Clinical and Developmental Immunology. 2013;2013.

12. Liu J, Hamrouni A, Wolowiec D, Coiteux V, Kuliczkowski K, Hetuin D, et al. Plasma cells from multiple myeloma patients express B7H1 (PD-L1) and increase expression after stimulation with IFN- $\gamma$ and TLR ligands via a MyD88-, TRAF6-, and MEK-dependent pathway. 2007;110(1):296-304.

13. Collins F, Lander E, Rogers J, Waterston R, Conso IJN. Finishing the euchromatic sequence of the human genome. 2004;431(7011):931-45.

14. Shenouda SK, Alahari SKJC, reviews $\mathrm{m}$. MicroRNA function in cancer: oncogene or a tumor suppressor? 2009;28(3):369-78.

15. Giza DE, Vasilescu C, Calin GAJEoobt. MicroRNAs and ceRNAs: therapeutic implications of RNA networks. 2014;14(9):1285-93.

16. Wang Q, Lin W, Tang X, Li S, Guo L, Lin Y, et al. The roles of microRNAs in regulating the expression of PD-1/PD-L1 immune checkpoint. 2017;18(12):2540.

17. Wang W, Sun J, Li F, Li R, Gu Y, Liu C, et al. A frequent somatic mutation in CD274 3'UTR leads to protein over-expression in 
gastric cancer by disrupting miR-570 binding. 2012;33(3):480-4.

18. Le Beau MM, Lemons RS, Espinosa R3, Larson RA, Arai N, Rowley JD. Interleukin-4 and interleukin-5 map to human chromosome 5 in a region encoding growth factors and receptors and are deleted in myeloid leukemias with a del (5q). 1989;73(3):647-50.

19. Cui SY, Wang R, Chen LBJJoc, medicine $\mathrm{m}$. Micro RNA-145: a potent tumour suppressor that regulates multiple cellular pathways. 2014;18(10):1913-26.

20. Ding Y, Zhang C, Zhang J, Zhang N, Li T, Fang $\mathrm{J}$, et al. miR-145 inhibits proliferation and migration of breast cancer cells by directly or indirectly regulating TGF- $\beta 1$ expression. 2017;50(5):1701-10.

21. Osborne C, Wilson P, Tripathy DJTo. Oncogenes and tumor suppressor genes in breast cancer: potential diagnostic and therapeutic applications. 2004;9(4):361-77.

22. Han Y, Liu D, Li LJAjocr. PD-1/PD-L1 pathway: current researches in cancer. 2020;10(3):727.

23. Payandeh Z, Khalili S, Somi MH, MardSoltani M, Baghbanzadeh A, Hajiasgharzadeh $\mathrm{K}$, et al. PD-1/PD-L1-dependent immune response in colorectal cancer. 2020;235(78):5461-75.

24. Ghebeh H, Mohammed S, Al-Omair A, Qattant A, Lehe C, Al-Qudaihi G, et al. The B7-H1 (PD-L1) T lymphocyte-inhibitory molecule is expressed in breast cancer patients with infiltrating ductal carcinoma: correlation with important high-risk prognostic factors. 2006;8(3):190-8

25. Xu S, Tao Z, Hai B, Liang H, Shi Y, Wang T, et al. miR-424 (322) reverses chemoresistance via $\mathrm{T}$-cell immune response activation by blocking the PD-L1 immune checkpoint. 2016;7(1):1-13.

26. Van Der Kraak L, Goel G, Ramanan K, Kaltenmeier C, Zhang L, Normolle DP, et al. 5-Fluorouracil upregulates cell surface B7-H1 (PD-L1) expression in gastrointestinal cancers. 2016;4(1):1-8.
27. Goel G, Ramanan K, Kaltenmeier C, Zhang L, Freeman GJ, Normolle DP, Tang D, Lotze MT. Effect of 5-fluorouracil on membranous PD-L1 expression in colon cancer cells. 2016;34(4):592.

28. Hamam R, Hamam D, Alsaleh KA, Kassem M, Zaher W, Alfayez M, et al. Circulating microRNAs in breast cancer: novel diagnostic and prognostic biomarkers. 2017;8(9):e3045e.

29. Cheng Y, Shen PJFio. miR-335 acts as a tumor suppressor and enhances ionizing radiation-induced tumor regression by targeting ROCK1. 2020;10:278.

30. Ardekani AM, Naeini MMJAjomb. The role of microRNAs in human diseases. 2010;2(4):161.

31. MacFarlane L-A, R Murphy PJCg. MicroRNA: biogenesis, function and role in cancer. 2010;11(7):537-61.

32. Iio A, Nakagawa Y, Hirata I, Naoe T, Akao YJMc. Identification of non-coding RNAs embracing microRNA-143/145 cluster. 2010;9(1):1-7.

33. Wang C-J, Zhou Z-G, Wang L, Yang L, Zhou $\mathrm{B}, \mathrm{Gu}$ J, et al. Clinicopathological significance of microRNA-31,-143 and-145 expression in colorectal cancer. 2009;26(1):27-34

34. Peng X, Guo W, Liu T, Wang X, Tu Xa, Xiong $\mathrm{D}$, et al. Identification of miRs-143 and-145 that is associated with bone metastasis of prostate cancer and involved in the regulation of EMT. 2011;6(5):e20341.

35. Yan X, Chen X, Liang H, Deng T, Chen W, Zhang $S$, et al. miR-143 and miR-145 synergistically regulate ERBB3 to suppress cell proliferation and invasion in breast cancer. 2014;13(1):1-14.

36. Hu J, Guo H, Li H, Liu Y, Liu J, Chen L, Zhang J, Zhang N. MiR-145 regulates epithelial to mesenchymal transition of breast cancer cells by targeting Oct4. 2012;7(9):e45965.

37. Quan Y, Huang X, Quan XJOl. Expression of miRNA-206 and miRNA-145 in breast cancer and correlation with prognosis. 2018;16(5):6638-42. 